\title{
Łukasz Goniak
}

(TVP Bydgoszzz)

\section{Tradycyjne media vs nowe możliwości Czy rzeczywiście redefinicja zawodu dziennikarza?}

Streszczenie: W prezentowanej pracy autor ukazuje i analizuje zmiany, jakie pod wpływem zjawiska konwergencji mediów dokonują się obecnie w telewizyjnych redakcjach informacyjnych. Wśród poruszonych zagadnień czytelnik znajdzie m.in. opis przebiegu oraz wybranych sposobów i form procesu ",otwarcia się" telewizji na widzów. Autor wskazuje nie tylko na rozwój rzeczywistych narzędzi komunikacji na linii odbiorca-redakcja. Sporo uwagi poświęca też mechanizmom, które mają za zadanie wyeksponować (przerysować) otwartość na odbiorcę. Wydaje się bowiem, że telewizja postrzegana dotychczas jako medium jednokierunkowe (co wynika w dużej mierze z takiej jej istoty), chcąc przyciągnąc uwage „nowego odbiorcy”, jest skazana w wielu sytuacjach na „zaklinanie rzeczywistości". Znajduje to odzwierciedlenie m.in. w strukturze serwisów informacyjnych, treści i formie tworzonych przekazów oraz szybkości ich publikowania. Co ważne, omówione zmiany nie pozostają bez wpływu na pracę osób zaangażowanych w tworzenie przekazu, w szczególności dziennikarzy. Wydaje się, że profesja ta obecnie, ontologicznie i funkcjonalnie, zmienia się. Czy jest to jednak modyfikacja na tyle istotna, iż można mówić o redefinicji zawodu dziennikarza? Autor odpowiada na to pytanie i opisuje wskazane wyżej przekształcenia w oparciu o obserwację i analizę jednego z polskich, regionalnych serwisów informacyjnych. Wydaje się jednak, że podobne trendy z powodzeniem można dostrzec $w$ wielu innych redakcjach i dziennikach telewizyjnych.

Słowa kluczowe: demokratyzacja mediów, interakcyjność, konwergencja mediów, redefinicja dziennikarstwa

\section{Wprowadzenie}

Dojawienie się, szybki rozwój i upowszechnienie się nowych mediów nie pozostały bez wpływu na te tradycyjne, które - chcąc dotrzymać kroku "wyrastającej konkurencji" - musiały dostosować się do wymogów 
„nowego odbiorcy"1. Jednym z ważniejszych wyzwań - choć nie jedynym - przed którym stanęły, było zniwelowanie tak charakterystycznego dla nich jednokierunkowego przekazu. Niniejsza praca będzie próbą nakreślenia dotychczasowego przebiegu oraz wybranych sposobów i form procesu „otwarcia się" telewizji na widzów. Autor dokona tego na przykładzie emitowanego na antenie bydgoskiego Oddziału Telewizji Polskiej programu informacyjnego „Zbliżenia”. Jako współpracownik ośrodka, był nie tylko świadkiem, ale także uczestnikiem wskazanych przemian. Perspektywa ta pozwala stwierdzić, że dokonana - ale też ciągle trwająca - mediamorfoza telewizji nie pozostała bez wpływu na pracę osób zatrudnionych ${ }^{2}$ w medium, w tym szczególnie dziennikarzy. Co dokładnie się zmieniło i czy jest to modyfikacja na tyle istotna, że dezaktualizuje powstałe do tej pory definicje dziennikarstwa? Jaki wpływ ma na to „dziennikarstwo uczestniczące"? W końcu - jakie są zagrożenia związane z jego wzrastającą popularnością? Między innymi na te pytania autor postara się odpowiedzieć w niniejszej pracy.

\section{Definicja zawodu dziennikarza}

W literaturze przedmiotu brakuje zgody co do tego, kogo należy zaliczyć do grona dziennikarzy. Przyczyn takiego stanu rzeczy jest kilka. Wskazuje się m.in. na ciągłą ewolucję dziennikarstwa, które obecnie ulega procesowi profesjonalizacji. $Z$ drugiej jednak strony - i to należy uznać za kolejną "trudność" - coraz szersze ujmowanie konstytucyjnego prawa do "rozpowszechniania informacji, opinii i poglądów" powoduje, że pod opisywany zawód zaczyna „podczepiać się" coraz więcej osób. Jak pisze Stanisław Michalczyk [2006: 51], „,ten przywilej posiadają nie tylko dziennikarze i pra-

1 Zmiana, która nastąpiła wraz z powstaniem (początek lat 90. XX w.) i spopularyzowaniem się stron WWW, spowodowała znaczne osłabienie silnego dotąd podziału na wydawców (nadawców) i odbiorców. Tym samym „tworzenie i rozpowszechnianie informacji stało się równie łatwe jak konsumowanie" [Zwiefka-Chwałek 2009: 8]. Konsekwencją przełamania dotychczasowej, tak charakterystycznej nadal dla prasy, radia i telewizji, bariery jednokierunkowości była „rekonfiguracja modelu komunikowania”, która przyniosła z kolei zmianę "mentalnych i psychologicznych nastawień odbiorcy [...] do formy przekazu” [Bauer 2007: 53]. Parafrazując starą, łacińską paremię, można stwierdzić, że powszechna w społeczeństwie stała się postawa "nic o nas bez nas".

2 Autor ma tutaj na myśli nie tylko osoby związane z TVP SA stosunkiem pracy, ale także współpracowników, których z telewizją łączy stosunek cywilnoprawny powstały z mocy umowy o dzieło lub zlecenie. 
cownicy mediów, ale również osoby niezwiązane na co dzień z mediami". Prawo to nabiera szczególnego znaczenia w dobie komputeryzacji i rozpowszechnienia Internetu. W ramach dziennikarstwa pojawiły i wciąż pojawiają się nowe "specjalizacje" (postacie), żeby wspomnieć tylko o dziennikarstwie internetowym, obywatelskim czy "uczestniczącym" ${ }^{\prime 3}$. Powstaje także wiele grup zawodów „okołomedialnych", m.in. infoblogerzy, selekcjonerzy informacji czy specjaliści od PR. Dodatkowo żurnaliści nierzadko łączą swoją prace w mediach z innymi zajęciami [Kononiuk, Michalski 1998: 11]. Wskazane wyżej kwestie ${ }^{4}$ oraz to, że obecnie znacznie zmieniła się forma prezentacji informacji, tj. coraz częściej miesza się ona z rozryw$\mathrm{ką}^{5}$, na tyle komplikują sytuację, że dziś trudno o jedną, uniwersalną definicję dziennikarza.

W literaturze pojawia się wiele propozycji. Uwzględniając opisane do tej pory problemy, a przede wszystkim cel, jaki autor we wstępie sobie postawił, na potrzeby niniejszej pracy postanowiono przyjąć definicję zaproponowaną przez Stanisława Mocka [2006: 27]. Według niego za dziennika-

${ }^{3}$ W tym miejscu zasadne wydaje się uporządkowanie pewnych kwestii pojęciowych związanych z wymienionymi typami dziennikarstwa. O ile bowiem zdefiniowanie terminu "dziennikarstwo internetowe" nie nastręcza większych problemów, o tyle dwóch pozostałych, tj. „dziennikarstwo obywatelskie” oraz „dziennikarstwo uczestniczące”, i owszem. W literaturze przedmiotu wymienionych pojęć używa się najczęściej zamiennie, określając w ten sposób „dziennikarza amatora”, który przejmuje częściowo „odpowiedzialność za zbieranie, organizowanie i przetwarzanie danych za dziennikarzy i ich przełożonych". To "Osobowe" ujęcie widoczne jest np. u Szpunar [2008: 142]. Opisywane terminy znacznie rzadziej bywają rozgraniczane - przy czym zmianie ulega jedynie definicja dziennikarstwa obywatelskiego. Za takich uważa się żurnalistów profesjonalistów, którzy przez swoją działalność przyczyniają się do budowy społeczeństwa obywatelskiego. W tym tradycyjnym rozumieniu dziennikarstwa jako instytucji społecznej, które ukształtowało się w przeszłości, sprawy każdej osoby są równie ważne. Aby jeszcze bardziej uwypuklić opisywaną różnicę, można przytoczyć - spotykane w literaturze angielskiej - odpowiedniki obu terminów: citizen "noun" journalism (podejście „osobowe") i civic "adjective" journalism (podejście tradycyjne). Widać więc, że w języku angielskim udało się uchwycić omawianą różnicę. Autor, na potrzeby niniejszej pracy, za właściwe przyjmuje drugie z zaprezentowanych podejść, tj. rozgraniczające oba terminy. Więcej zob. Zwiefka-Chwałek [2009: 11-14].

${ }^{4}$ Oczywiście, przeszkód "stojących" na drodze do stworzenia jednej, uniwersalnej definicji terminu „dziennikarz" jest znacznie więcej. Na zupełnie inne wskazaliby zapewne prawnicy. Dlatego wyliczenie autora należy traktować jako przykładowe.

${ }^{5}$ Oprócz opisywanego zjawiska infotainment, warte odnotowania jest również - coraz częstsze - występowanie dziennikarzy informacyjnych w programach rozrywkowych, także w roli prowadzącego, np. Jarosław Kuźniar z TVN 24, który w ostatnim czasie zdecydował się na "prowadzenie" muzycznego show X Factor, oraz Michał Adamczyk - prezenter Wiadomości TVP, w telewizji publicznej występujący również w roli gospodarza sobotniego wydania programu „Kawa czy herbata”. Podobnych przykładów jest więcej. 
rza należy uznać osobę , „która w dobie mediów masowych w prasie, radiu, telewizji lub mediach elektronicznych zawodowo [wyróżn. Ł. G.], w sposób trwały, twórczy, intelektualnie inspirujący i warsztatowo profesjonalny [wyróżn. Ł. G.] zajmuje się gromadzeniem, doborem, obróbką oraz rozpowszechnianiem informacji i komentarzy". Rozwiązanie to wydaje się o tyle zasadne, że zaprezentowana definicja podkreśla cechy dziennikarstwa w ujęciu tradycyjnym, tj. działalność "zawodową" $i$ "warsztatowo profesjonalną". Tym samym pomija ona (nie włącza w definiens) aktywność internautów, którą przyjęto nazywać "dziennikarstwem uczestniczącym", a która wydaje się niejako esencją zmiany, tj. przejścia od społeczeństw tradycyjnych do informacyjnych. W tych drugich bierny odbiorca (widz) staje się nie tylko aktywnym użytkownikiem (może w mniejszym lub większym stopniu wpływać na przekaz), ale również „twórcą” (może go sam kreować)

\section{Zmiany i otwarcie telewizji}

Ta niespotykana dotąd "otwartość" stała się szczególnym wyzwaniem dla telewizji jako "medium najmniej podatnego na interaktywność" [Bauer 2007: 53] $]^{7}$ Wydaje się wręcz, że jednokierunkowość przekazu należy - na tym etapie technologicznego rozwoju - uznać nadal za jej „kwintesencję". W tych okolicznościach, ważniejsze od „pościgu” za Internetem - „wzor-

${ }^{6}$ Niezbędne w tym miejscu - dla prawidłowego zrozumienia intencji autora - może okazać się poczynienie kilku dodatkowych uwag metodologicznych. Celem tej pracy nie jest bowiem uzyskanie odpowiedzi na pytanie, czy i jak zmienia się definicja dziennikarza od momentu pojawienia się zjawiska nazwanego "dziennikarstwem uczestniczącym", traktowanego - a priori - jako nowego rodzaju (specjalizacje) dziennikarstwo. Autorowi zależy raczej na rozstrzygnięciu, czy rzeczywiście i jak działalność internautów wpływa na pracę żurnalisty i czy w związku z tym możemy mówić o redefinicji zawodu dziennikarza. Treść pytań różni założona perspektywa - nie da się ukryć, że drugie podejście odznacza się pewnym sceptycyzmem „uznaniowym” w stosunku do nowego rodzaju żurnalizmu. Dlatego - krótko rzecz ujmując - można powiedzieć, że: o ile w pierwszym z nich należałoby najpierw „zbadać", czy nowo powstałe zjawisko mieści się w dotychczasowej definicji dziennikarza, a jeśli nie, to jaka winna ona być, aby tak się stało (późniejsze porównanie „starej” " „nowej" definicji będzie ukazaniem zmian, jakie się dokonały), o tyle w drugim przyjętym przez autora w niniejszej pracy - następuje weryfikacja dotychczasowej definicji z uwzględnieniem przejawów wskazanego zjawiska.

7 Jak stwierdza autor: „Telewizja analogowa i cyfrowa posługująca się emisją rozsiewczą (antenową) nie może być interaktywna, bowiem odbiorca nie posiada nadajnika (również antenowego), za pomocą którego mógłby reagować na docierające do niego przekazy" [Bauer 2007: 54]. 
cem" interaktywności - okazać się może stworzenie pewnego pozoru „otwartości”, tj. „zaklęcie rzeczywistości”, w której telewizja, głównie przez przekonanie odbiorcy, że ma on "realny" wpływ na przekaz (może go modyfikować), skróci powstały dystans ${ }^{8}$. Dlatego - zdaniem autora - warto przyjrzeć się nie tylko zmianom, jakie dokonały się i nadal zachodzą na płaszczyźnie środków komunikacji udostępnianych widzom przez telewizję (Internet, telefon i kontakt osobisty) - które w rzeczywisty sposób pozwalają wpływać na treść telewizyjnego przekazu, ale także - co, biorąc pod uwagę "specyfikę" tego medium, w którym najistotniejszą rolę generalnie odgrywa obraz, może okazać się nawet ważniejsze - przekształceniom widocznym bezpośrednio na szklanym ekranie.

\section{Internet}

Od lutego 2009 roku widoczne są wyraźne zmiany odnoszące się do roli Internetu ${ }^{10} \mathrm{w}$ działalności redakcji. Przekształcenia dokonywały się na dwóch płaszczyznach:

8 O tych pozorach uprzywilejowania "nowego odbiorcy", który niejako może współdecydować o kształcie przekazu, wspomina także Janina Hajduk-Nijakowska [2010: 11]. Autorka pisze: „nadawcy zabiegają przecież głównie o to, by odbiorcy byli przekonani, że wychodzą naprzeciw ich oczekiwaniom i potrzebom. Dzieje się to jednak głównie poprzez manipulowanie odbiorcami: wywoływanie określonych potrzeb i inspirowanie oczekiwanej przez nadawcę formy aktywności oraz podobnej reakcji".

9 Wtedy to na dyrektora bydgoskiego ośrodka został powołany dotychczasowy szef informacji TVP Info Tomasz Pietraszak, który na tym stanowisku pozostaje do dziś (27.03.2011). Autor datę tę przyjmuje za graniczną - od tego momentu bowiem widać m.in. zmianę polityki informacyjnej ośrodka. O jej kształcie, tuż po powołaniu, mówił sam Pietraszak. Zapowiedział, że telewizja pod jego kierownictwem będzie bardziej „przyjazna ludziom i regionowi”, „aktywna i opiniotwórcza” [Przybylski 2009]. Pietraszak zaznaczył jednocześnie, że: „Wiosenna ramówka jest już zaplanowana, latem dużych zmian się nie wprowadza. Tymczasem więc żadnych zmian nie planuję. Nowej jakości widzowie mogą spodziewać się jesienią". Jako konkretny cel wymienił zdynamizowanie „Zbliżeń" [jot 2009]. W kwietniu 2009 r. potwierdził to Jarosław Lewandowski - nowy kierownik Sekcji Audycji Informacyjnych i Sportowych. Na łamach bydgoskiej „Gazety Wyborczej” przekonywał: „Dziennik przejdzie graficzny »lifting", zostanie zdynamizowany, będzie więcej wejść na żywo, pojawi się więcej informacji” [al 2009]. Zmianom, które dokonywały się w „Zbliżeniach", towarzyszyły także przekształcenia strony WWW, która miała wypełnić ",braki antenowe".

10 Traktowanego tutaj nie jako środek masowego przekazu (źródło informacji), z którym rywalizuje obecnie telewizja (element równości), ale narzędzie techniczne (element podporządkowania). 
Po pierwsze, jeśli chodzi o przekaz adresowany do widzów:

a) W dobie permanentnego "wyścigu informacyjnego" oraz w związku z ograniczonym i relatywnie późnym czasem antenowym pasma regionalnego (od 6 września 2010 roku główne pasmo lokalne emitowane jest w godz. 17-2011), w trakcie którego emitowany jest także serwis informacyjny (Flash ${ }^{12}$ o godz. 17; główne wydanie o godz. 18.30), nieodzowne stało się zapewnienie odbiorcom dostępu do bieżących wydarzeń ${ }^{13}$. Odpowiedzialny za to, ,, aby strona żyła cały dzień", był na początku (od maja 2009 roku) jeden, a od sierpnia 2010 roku dwóch stałych dziennikarzy internetowych. Obecnie każdego dnia na stronie pojawia się od 8 do 20 informacji ${ }^{14}$. Tym samym WWW, uzupełniając ofertę wydania, stawała się kolejnym potencjalnym elementem „wiążącym" odbiorcę z redakcją ${ }^{15}$.

${ }^{11}$ Co jakiś czas - zwykle przy wprowadzaniu nowej ramówki - czas pasma ulega nieznacznej zmianie (ok. 0,5-1 godz.). Korekty, mimo że niewielkie, budzą sprzeciw regionalnych ośrodków - zob. [Uchwała Rady Programowej TVP Bydgoszcz].

12 Krótki dziennik informacyjny, składający się z trzech „tematów”, prezentowanych w formie 30-sekundowej „zajawki”, uzupełniony o prognozę pogody, kończący się zaproszeniem do obejrzenia głównego wydania, w którym „powiemy Państwu więcej na te tematy".

13 Jak pisze bowiem Zwiefka-Chwałek [2009: 169], „w przypadku przekazu internetowego czas nie odgrywa żadnej roli - wydarzenia opisywane są na bieżąco, a informacje nieustannie aktualizowane i dostępne w każdej chwili".

14 Początkowo były to tylko własne teksty reporterów „Zbliżeń". Z czasem na stronie zaczęto umieszczać także informacje powstałe na podstawie doniesień Polskiej Agencji Prasowej czy te, które danego dnia nie „weszły do serwisu”, a były "warte” odnotowania. Dla przykładu - zob. http://www.tvp.pl/bydgoszcz/aktualnosci/kryminalne/napadli-pare -z-dzieckiem-dla-20-zlotych/4225702, 29.03.2011. Ukazujące się informacje są nierzadko wzbogacone materiałami z wejść "na żywo” na antenę ogólnopolską (szczególnie TVP Info) oraz pochodzącymi ze źródeł zewnętrznych, w tym szczególnie od Policji. Oczywiście, oprócz typowo newsowych materiałów, na stronie są także umieszczane inne produkcje TVP Bydgoszcz. Autor, w związku z przyjętym w niniejszej pracy tematem, wskazuje jednak jedynie na te "elementy", które są bezpośrednio związane z pracą redakcji "Zbliżeń".

15 Warto w tym miejscu wspomnieć jeszcze o ówczesnej, bardzo złej sytuacji finansowej ośrodków regionalnych, co zapewne przyczyniło się do - większego niż dotychczas - zainteresowania rolą Internetu. Telewizja regionalna, w związku z kryzysem i ciągłym spadkiem wpływów z abonamentu, z którego jest finansowana, musiała - w coraz większym stopniu - koszty swojej działalności pokrywać ze źródeł własnych, uzyskanych m.in. z reklamy oraz od zewnętrznych sponsorów [jar 2011]. Według Press wielkość dofinansowania sięgnęła połowy budżetu programowego TVP Bydgoszcz [RUT 2010]. Jak już wcześniej wskazano, Internet miał pomóc w walce o „klienta”. Co więcej, wkrótce sama witryna stała się miejscem prezentowania reklam (In-stream VideoAd). Pierwsze - operatora telefonii komórkowej Play - pojawiły się na przełomie stycznia i lutego 2011 r. Spoty reklamowe 
b) Zaktualizowana strona internetowa otworzyła jednocześnie nowe możliwości promocji wizerunku „Zbliżeń” jako medium, które trzyma "rękę na pulsie" i podaje zawsze "najświeższe informacje”. Niejednokrotnie dawano temu wyraz w czasie emisji serwisu słowami: „TVP Bydgoszcz o tym temacie, jako pierwsza, informowała na swojej stronie internetowej". Jak piszą Shayne Bowman i Chris Willis [2003: 59], witryna w takim przypadku nie ma zastępować medium, a jedynie stać się „żyjącą i oddychającą $24 \times 7 \times 365$ dni w roku przybudówką" marki. W ten sposób zamyka się drogę do „oskarżeń" o przekazywanie „spóźnionych” informacji.

c) Strona internetowa miała także służyć zainteresowaniu widza realizowanymi w poszczególnych dniach przez reporterów „Zbliżeń" tematami. Materiały, których krótki opis jako "temat dnia" pojawiał się na WWW, w całości można było obejrzeć w serwisie. Taką też informację użytkownik uzyskiwał, przeglądając witrynę. W kontekście „papierowych gazet” o tej „promocyjnej” funkcji stron internetowych wspomina Szpunar [2008: 146], która stwierdza, że:,,istotne jest tutaj takie przygotowanie artykułu w wersji online, które powinno inicjować kontakt z czytelnikiem, kreować potrzebę sięgnięcia po więcej".

d) W sierpniu 2010 roku, po ukończeniu tworzenia nowego, interaktywnego portalu, użytkownicy otrzymali łatwiejszy i szerszy niż dotychczas dostęp do produkcji z całego kraju ${ }^{16}$. Wynikało to z połączenia w jedną całość wszystkich stron WWW TVP. Konsekwencją tego była zmiana layoutu (rys. 1 - przed zmianą; rys. 2 - po zmianie) tak, że obecnie, zarówno na szczeblu ogólnopolskim, jak i regionalnym, witryny prezentują tę samą szatę graficzną.

Po drugie, jeśli chodzi o przekaz skierowany przez widzów do redakcji:

a) Wszyscy chętni zostali zaproszeni do nadsyłania zdjęć, filmików i plików mp3. Na stronie utworzono specjalną zakładkę informującą o ta-

poprzedzały wybrany przez użytkownika materiał filmowy. Ich liczba została ograniczona do jednej emisji na godzinę dla użytkownika - zob. http://brtvp.pl//mozliwosci/TVP.PL/ oferta/, 30.03.2011. Trudno obecnie stwierdzić, jaka jest dzienna liczba odwiedzin strony www.tvp.pl/bydgoszcz. Na pewno "regionalny wortal” to jedna z wielu "cegiełek”, które w sumie - jak podaje Telewizja Polska na swojej stronie internetowej - we wrześniu 2010 r. codziennie odwiedzało półtora miliona osób.

${ }^{16}$ Obecnie www.tvp.pl udostępnia swoim użytkownikom ok. 8 tys. programów z całego kraju - zob. http://brtvp.pl//mozliwosci/TVP.PL, 30.03.2011. 


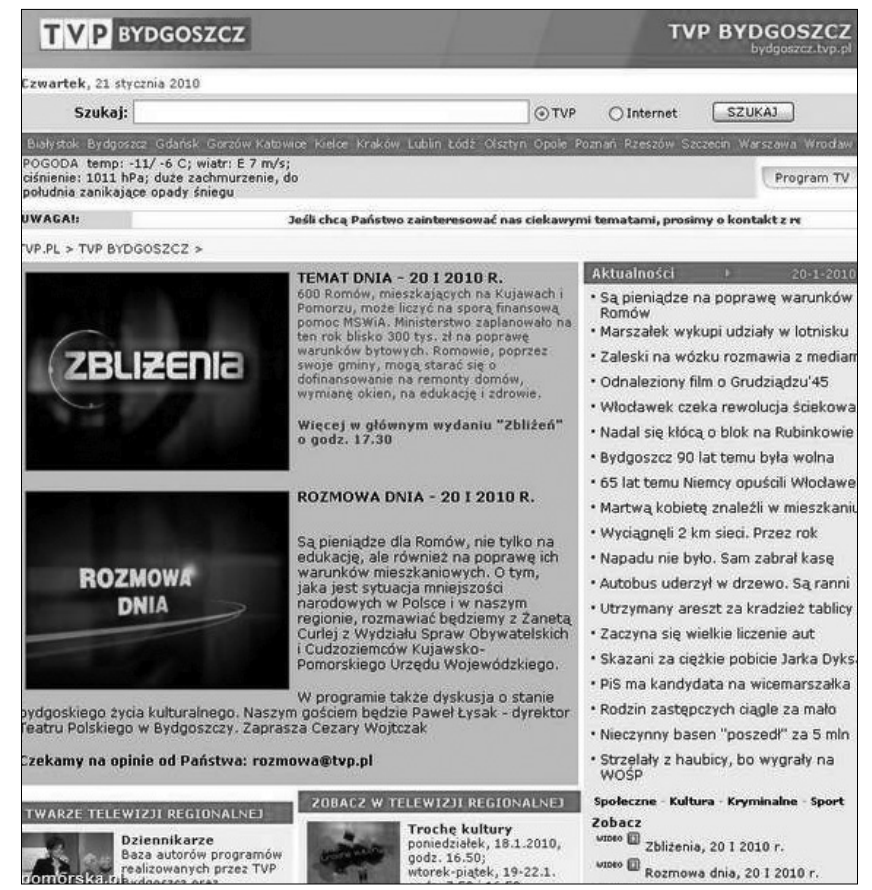

\section{Rysunek 1}

Źródło: www.pomorska.pl.

kiej możliwości, będącą jednocześnie galerią najciekawszych i najbardziej interesujących spośród nich ${ }^{17}$. Dodatkową motywacją dla potencjalnych „reporterów ma być szansa zaprezentowania wybranych wiadomości podczas „Zbliżeń". Z analizy serwisu wynika jednak, że zdarza się to niezwykle rzadko. W styczniu i lutym taka sytuacja miała miejsce dwukrotnie (po jednym razie w każdym miesiącu) ${ }^{18}$. Przyczyn takiego stanu rzeczy zapewne jest kilka: począwszy od pasywności widzów i słabej jakości nadsyłanych plików, po dużą konkurencję ze strony innych, szczególnie ogólnopolskich redakcji ${ }^{19}$.

17 Pliki, aby pojawić się w galerii, dodatkowo muszą spełnić dwa kryteria: a) ilościowe - „nie może to być jedno, dwa zdjęcia"; b) jakościowe - „muszą nadawać się do publikacji”. Warunki te prawdopodobnie przyczyniły się do sytuacji, że w dziale "galeria" od początku roku pojawiło się zaledwie 7 pozycji (29.03.2011).

${ }^{18}$ W styczniu w „wejściu internetowym” (autor rozwija ten wątek w dalszej części pracy) została wykorzystana galeria zdjęć widza, dotycząca dziurawych nawierzchni dróg. Z kolei w lutym, w materiale Iwony Komisarek Długa droga (25.02.2011), do pokrycia części "filmu" użyto amatorskiego nagrania jednego z „,bohaterów".

19 Możliwość zaistnienia podczas emisji ogólnopolskiego serwisu np. „Faktów TVN”, 


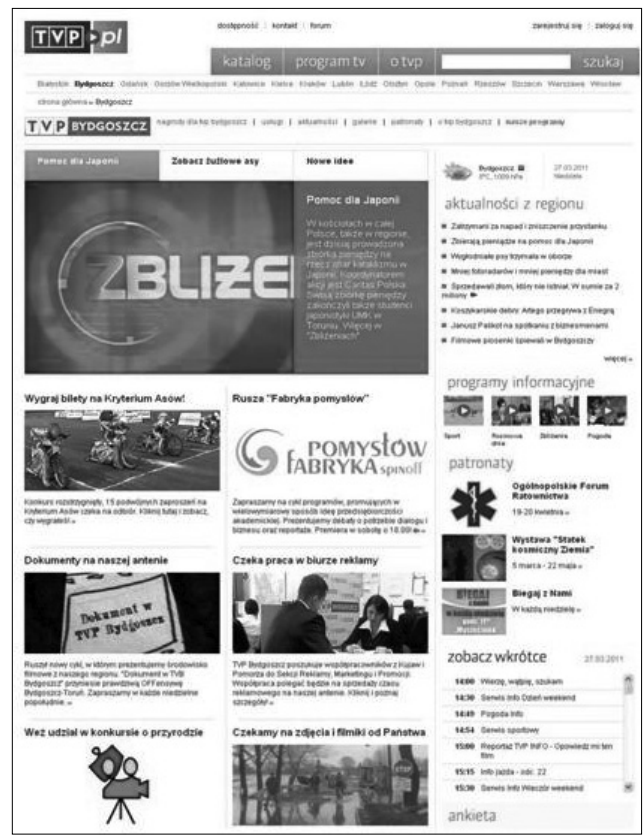

\section{Rysunek 2}

Źródło: www.tvp.pl/bydgoszcz.

b) Widzowie znacznie częściej decydują się na kontakt z redakcją w celu uzyskania pomocy przez nagłośnienie spraw niepokojących lub bezpośrednio ich dotyczących. Warto zauważyć, że zainteresowanie tego typu informacjami wzrosło po utworzeniu $\mathrm{w}_{\text {"Szpiglu"20 }}$ stałej pozycji nazwanej „interwencja” ${ }^{21}$. Od tego czasu każdego

które ogląda obecnie średnio ponad 4 mln Polaków (wg OBOP w marcu było to dokładnie 4 mln 340 tys.) - przy widowni "Zbliżeń" wahającej się w granicach od 80 do 200 tys. osób - to niejedyny argument powodujący, że na Kontakt24 TVN-u dociera więcej tego typu plików ( $w$ tym samym okresie, tj. od początku roku do końca marca, z województwa kujawsko-pomorskiego nadesłano 56 galerii zdjęć, filmików, informacji itd., z czego 7 zostało wykorzystanych przez redakcję portalu www.tvn24.pl, a dwa pojawiły się na antenie stacji). Wydaje się, że dużą rolę odgrywa fakt, że to właśnie TVN już w 2007 r. rozpoczął tego typu „współpracę" z widzami [Szewczyk 2007].

20 Jest to "szczegółowy rozkład jazdy programu" - więcej zob. [Żórawski 2010: 164].

${ }^{21}$ Oczywiście nie jest tak, że do tej pory takie prośby były całkowicie ignorowane. Owszem, materiały tego typu pojawiały się w serwisach, ale było to uzależnione tylko i wyłącznie od decyzji wydawcy. Obecne rozwiązanie niejako pozbawia go „uznaniowości” i „wymusza" uwzględnienie interwencji w serwisie. Zmieniają się więc "potrzeby" wydawców, a wraz z nimi wymagania kierowane pod adresem reporterów, co z kolei „wymusza” większe zainteresowanie tego typu sprawami. Więcej o interwencji autor pisze w dalszej części pracy. 
dnia w serwisie można obejrzeć co najmniej jeden - wyeksponowany w sposób szczególny - materiał realizowany na prośbę lub $z$ udziałem widzów ${ }^{22}$. Nie pozostało to niezauważone przez odbiorców. Mimo że trudno w tym miejscu o dane w sposób bezpośredni potwierdzające, to z obserwacji autora wynika, że liczba zgłaszanych próśb o pomoc w ostatnim czasie wzrosła ${ }^{23}$.

\section{Telefon i kontakt osobisty}

Komplikacje $z$ dokładnym określeniem liczby zgłaszanych spraw wynikają m.in. $z$ faktu, że Internet to niejedyne medium, za pomocą którego widzowie kontaktują się z redakcją. Równie często korzystają z telefonu, dzwoniąc bądź do dyżurującego tego dnia "newsowca”, bądź do poszczególnych reporterów. Dziennie z redakcją w ten sposób kontaktuje się do 10-15 osób. Większość osób telefonuje w trakcie lub tuż po głównym wydaniu „Zbliżeń" i - w zdecydowanej większości - są to komentarze dotyczące wyemitowanych właśnie materiałów. Telefon w tym celu wykorzystywany jest znacznie częściej niż sieć ${ }^{24}$. Z kolei bardzo rzadko zdarza się, by chęć wyrażenia swojej opinii o materiale skłoniła kogokolwiek do osobistej wizyty w redakcji. Najczęściej powodem „odwiedzin” jest prośba o interwencję ${ }^{25}$.

\section{Nowa oprawa serwisu informacyjnego}

Opisane do tej pory kanały komunikacji - paradoksalnie - mogą okazać się jedynie niezbędną do osiągnięcia założonego celu pomocą. Dzięki nim

${ }^{22}$ W związku z tym, że serwisy weekendowe najczęściej są krótsze od tych w pozostałe dni tygodnia, element „ekspozycji” nie zawsze występuje w soboty, a prawie w ogóle w niedziele. Podobnie rzecz ma się z założeniem o co najmniej jednej interwencji w serwisie.

${ }^{23}$ Istotna przy tym może okazać się motywacja, którą kierują się często osoby zgłaszające się do redakcji. Autor wróci do tego zagadnienia w dalszej części pracy, omawiając zagrożenia, które wiążą się z „otwarciem" telewizji na widza.

${ }^{24}$ Warto wspomnieć, że jedyną dostępną formą komunikacji z redakcją przez Internet jest obecnie poczta elektroniczna. TVP Bydgoszcz, w przeciwieństwie do niektórych innych oddziałów (Białystok, Kielce, Kraków), nadal nie dysponuje własnym forum. Brakuje również wykorzystania powszechnie dostępnych komunikatorów (np. Gadu-Gadu).

${ }_{25}$ Podobnie jak przy poprzednich kanałach komunikacji, także w tym przypadku trudno o jakiekolwiek dane określające częstotliwość zjawiska. Z obserwacji autora wynika, że liczba ta w tygodniu nie przekracza 20 osób. 
bowiem telewizja rzeczywiście otwiera się na odbiorcę, ale - jak już zostało to na początku zaznaczone - w przypadku tego medium, dla osiągnięcia pełnego efektu, tj. przekonania do siebie widza, równie ważne (jeśli nie ważniejsze od technicznych narzędzi) może okazać się odpowiednie wyeksponowanie zmian. O ile bowiem „dualizm ról" w sieci jest dla użytkowników czymś „normalnym" - czymś, do czego już "przywykli", o tyle możliwość wpływania na kształt telewizji jest pewną nowością ${ }^{26}$. Właśnie m.in. dlatego tak istotne jest nie tylko informowanie widzów o istnieniu tego typu rozwiązań, ale - co wydaje się ważniejsze - także pokazywanie „wyjątkowych" skutków ich funkcjonowania. Ma to wywołać u odbiorcy przekonanie (wrażenie), że telewizja rzeczywiście czeka na ich odpowiedź, zaangażowanie i aktywność ${ }^{27}$. W ten sposób wszystkie wymienione „opcje”, charakterystyczne przede wszystkim dla nowych, a nie tradycyjnych mediów, mogą stać się elementem „kojarzonym” także z telewizją ${ }^{28}$.

W dalszej części pracy autor zamierza, na podstawie analizy nowej, wprowadzonej we wrześniu 2010 roku oprawy „Zbliżeń", ukazać niektóre, pojawiające się w stacjach telewizyjnych, mechanizmy "eksponujące otwartość na odbiorcę". Jest to pewna propozycją, którą autor chciałby poddać pod rozwagę czytelnika. Wybór "Zbliżeń” jest o tyle zasadny, że - wydaje się - twórcom zmian w serwisie, oprócz zapowiadanego zdyna-

${ }^{26}$ Do tej pory "Jedenasta Muza" była medium, które autorytatywnie decydowało o kształcie przekazu. Jak stwierdza Dan Gillmor [2003: vi], newsy przypominały „wykład”. Obecnie, po wielu latach, pod naciskiem Internetu i „dziennikarstwa uczestniczącego", ich forma uległa zmianie - znacznie zbliżyła się do wzoru "konwersacji" czy "seminarium”.

${ }^{27}$ Oczywiście - aby w pełni oddać sytuację - należy wskazać, że w większości redakcji rzeczywiście tak właśnie jest, tzn. aktywni odbiorcy traktowani są już nie jako zagrożenie, a duży potencjał, który może przynieść wiele korzyści. W niniejszej pracy autorowi zależy jednak na ukazaniu pewnych mechanizmów i technik służących „wyeksponowaniu" zjawiska.

${ }^{28}$ Opisany „zabieg” nabiera szczególnego znaczenia w kontekście tezy postawionej przez Giovanniego Sartoriego [2007: 13-35]. Włoch stwierdza, że obecnie żyjemy w czasach homo videns, cywilizacji telewizji i „postmyślenia”, w której „telewidz staje się w większym stopniu zwierzęciem widzącym niż zwierzęciem symbolicznym". W epoce charakteryzującej się „prymatem obrazu, czyli dominacją tego, co widzialne, nad tym, co zrozumiałe”, przeważa - według politologa - „patrzenie bezrozumne”. Komunikat w postaci obrazu, który odbiorca otrzymuje, jest bowiem jasny i w miarę jednoznaczny. Odbiorca nie jest więc zmuszony do zastanawiania się nad sensem tego, co właśnie zobaczył. Tym samym - w zdecydowanej większości - przyswaja informacje automatycznie, bez refleksji, co charakteryzuje wiedzę alogiczną. Odmiennie - zdaniem autora - rzecz ma się ze słowem. Posługiwanie się nim w kontaktach zmusza do poszukiwania odpowiedniego do kontekstu znaczenia, wydobycia go z "głębi umysłu". Mamy więc do czynienia z procesem abstrakcyjnego myślenia, tak charakterystycznego dla wiedzy logicznej. 
mizowania, udało się także przekonać do kontaktu większą niż do tej pory liczbę widzów. Zdaniem autora złożyło się na to kilka czynników.

Po pierwsze: nie bez znaczenia była zmiana formuły prowadzenia serwisu. Po dokonanych modyfikacjach prezenter nie siedzi już - jak dotychczas - za stołem (rys. 3), a "wędruje” po całym studio (rys. 5, 10, 13). Na szczególną uwagę zasługuje samo jego wejście (początek serwisu), które można uznać za pewnego rodzaju element inicjujący interakcję (kontakt) $z$ widzem ${ }^{29}$. Prowadzący, przemieszczając się bowiem z głębi newsroomu (rys. 5) w stronę kamery (rys. 6), zwraca się przy tym do publiczności, co sprawia wrażenie, jakby „rozmawiał" z odbiorcą ${ }^{30}$, co oczywiście nie pozostaje bez wpływu na widza ${ }^{31}$.

${ }^{29}$ W literaturze socjologicznej powszechnie uznany jest pogląd, że bezpośredni kontakt wcale nie jest elementem sine qua non interakcji. Równie dobrze może ona przebiegać przy użyciu np. listu czy telefonu. Znacznie ważniejsza od formy jest treść i - na co wskazywał już Goffman - wywołane, świadomie lub nie, wrażenia, które pojawiają się w procesie interakcji [Szacka 2003: 122, 128].

30 Zapowiedź prezentera pełni funkcję fatyczną, którą jako pierwszy opisał Bronisław Malinowski [Kiklewicz 2006: 138-143]. Antropolog w ten sposób określił możliwe, odrębne zastosowanie języka, który w pewnych sytuacjach, użyty „nie jako środek manifestacji znaczeń", a narzędzie realizacji działalności, „tworzy jednoczące więzi przez samą wymianę słów". Zmierza tym samym do „stworzenia i podtrzymywania socjalnego oraz psychicznego kontaktu podmiotów". Dzieje się tak m.in. dlatego, że w komunikacji fatycznej „zadanie odbiorcy nie polega na aktywnym przetwarzaniu percypowanych treści ani na programowaniu jakichkolwiek, wynikających z nich czynności, ale na tym, aby zaakceptować komunikacyjną inicjatywę partnera poprzez kontynuację dialogu w zaproponowanym przez niego stylu" [Kiklewicz 2006: 140]. W literaturze przedmiotu można znaleźć podejścia, które ten rodzaj wypowiedzi traktują jako obecnie dominujący w mediach [Hajduk-Nijakowska 2010: 11].

${ }^{31}$ Zbudowana już bowiem na wstępie, opisana przez Gilberta Cohena-Seata, ,początkowa przypadkowość" wywołuje u odbiorcy napięcie, którego efektem są "różne możliwości zaangażowania psychologicznego, obejmujące pełen zakres stopni, od całkowitego zdystansowania się (człowiek, który wstaje i odchodzi zirytowany), poprzez ocenę krytyczną towarzyszącą odbiorowi, nieświadome oddanie się rozrywce bez odpowiedzialności, aż po uczestnictwo, fascynację lub też (w przypadkach patologicznych) prawdziwą hipnozę". Najczęściej masowemu odbiorcy towarzyszy ostatni z opisanych stanów. Według Cohena-Seata potwierdzają to doświadczenia przeprowadzone z użyciem elektroencefalografu, które pokazują, że „poruszający się obraz skłania widza do współdziałania [wyróżn. Ł. G.] z przedstawioną na ekranie akcją za pośrednictwem zjawiska indukowania postawy motorycznej: innymi słowy, jeżeli na ekranie jakaś postać wykonuje cios pięścią, to na elektroencefalografie widać pojawiające się w mózgu widza oscylacje odpowiadające »poleceniu«, jakie na zasadzie instynktowego naśladowania ośrodkowy układ nerwowy wydaje aparatowi mięśniowemu - polecenie to nie przekształca się w działanie tylko dlatego, że w większości przypadków jest ono słabsze niż to, jakie potrzeba, aby przejść od reakcji nerwowej do prawdziwego działania mięśni" [Eco 2010: 464-466]. Niemniej jednak zaznacza się w podświadomości widza wyraźna chęć odpowiedzi na „zaproszenie” - w tym przypadku telewizji. 


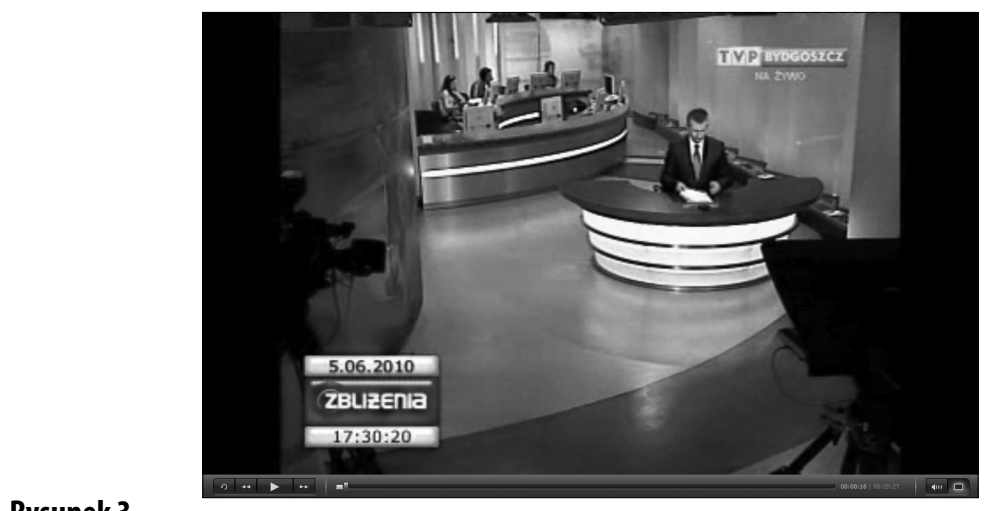

\section{Rysunek 3}

Źródło: www.tvp.pl/bydgoszcz.

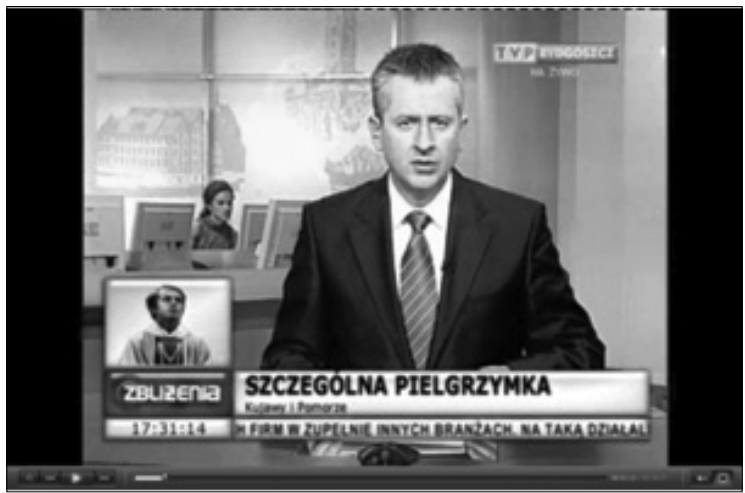

\section{Rysunek 4}

Źródło: www.tvp.pl/bydgoszcz.

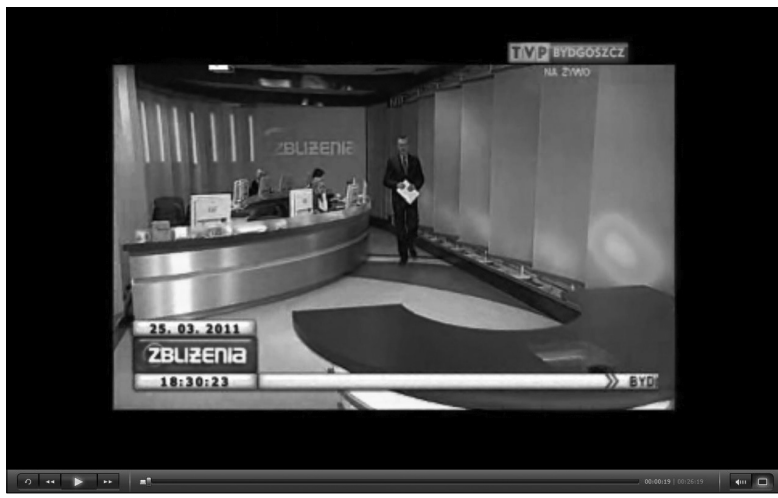

Rysunek 5. „Czy tak powinien wyglądać dom w XXI wieku?! Z pewnością nie”

Źródło: www.tvp.pl/bydgoszcz. 


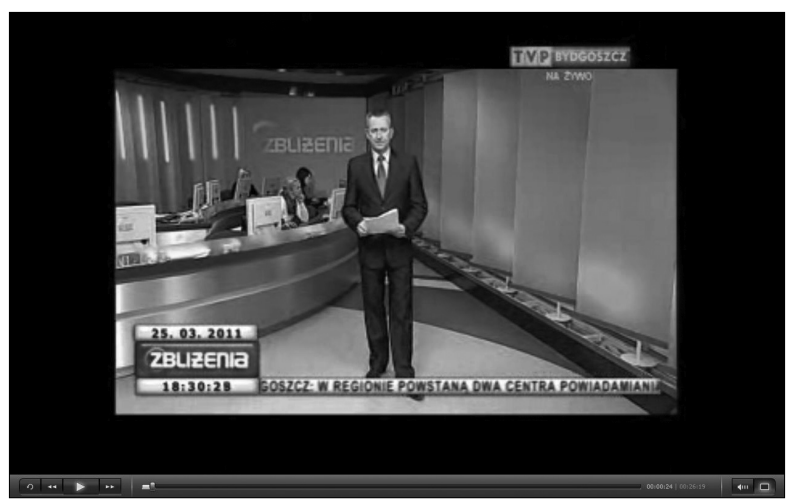

Rysunek 6. „Jarosław Lewandowski. Witam i zapraszam na Zbliżenia"32

Źródło: www.tvp.pl/bydgoszcz.

Po drugie: wywołaną już na samym początku „Zbliżeń" aktywność odbiorcy wydaje się jeszcze wzmacniać "tematyka" słów kierowanych do publiczności przez idącego prezentera. $Z$ reguły dotyczą one podejmowanej danego dnia przez reporterów „Zbliżeń" „interwencji” ${ }^{33}$, tj. materiału realizowanego - w zdecydowanej większości przypadków - na prośbę widzów, z ich udziałem, odnoszącego się do ich spraw. Tuż po zapowiedzi prowadzącego pojawiają się sami "bohaterowie", którzy w krótkich wypowiedziach („setkach") opowiadają najczęściej o swoich problemach. Całość stanowi kolejny, nowy element serwisu, nazywany potocznie „przed-headem"34.

Jak stwierdza Szpunar [2008: 142], takie „świadome oddanie głosu ludziom" - aktywnie zaangażowanym członkom danej społeczności - "ma sprzyjać większemu zaktywizowaniu i zaangażowaniu publiczności”. Ich udział dodatkowo jeszcze uwiarygodnia przekaz, który pokazuje telewizja. Ona sama postrzegana jest za to jako medium otwarte, współtworzone przez ludzij ${ }^{35}$. Na uwagę zasługuje fakt, że publiczność sygnał o „otwar-

32 Wydanie „Zbliżeń" z 25 marca 2011 r.

33 Zdarzają się przypadki odstępstw od tej zasady. Dzieje się tak najczęściej w momencie bardzo istotnych dla regionu wydarzeń.

${ }^{34}$ Zbitka, najczęściej dwóch „setek", połączona najciekawszymi zdjęciami z materiału, który zapowiada. Nazwa pochodzi od usytuowania tego elementu w "szpiglu" - występuje on tuż przed zbliżonymi „,konstrukcją” ",headami”, które - w formie flesza na początku serwisu - są zwiastunem „najciekawszych wydarzeń dnia”. W dalszej części „dziennika” pojawiają się jeszcze „śródy", które zwykle są pozbawione „setek".

35 Patrząc na wyniki przeprowadzonego w listopadzie 2010 r. przez IMM badania czterech najpopularniejszych serwisów ogólnopolskich (Fakty, Panorama, Wiadomości, Wydarzenia), które wskazały, że blisko 55\% pojawiających się w nich wypowiedzi to „głos ludzi” (43,3\% stanowią bezpośrednio zaangażowani, tj. „osoby, których dotyczy dany ma- 
tości" telewizji oraz zaproszenie do aktywności otrzymuje już na samym początku serwisu. Wytworzone w ten sposób „ogólne wrażenie" - zgodnie z założeniem teorii „efektu pierwszeństwa” - zdecydowanie ukierunkowuje odczyt późniejszych przekazów.

Po trzecie: warto zwrócić także uwagę na sam sposób „prezentacji” wspomnianej już „,interwencji". Do tej pory, jeżeli nawet mieliśmy tego typu materiał w "Zbliżeniach" - co wcale nie stanowiło reguły - był on niewyeksponowany, niczym nie wyróżniał się od pozostałych, a przez to "gubił się" w całości przekazu. Wydaje się, że nowa, inna niż przy pozostałych „tematach" formuła, w której prezenter w szerokim kadrze, na tle ekranu z pierwszym ujęciem „materiału”, czyta zapowiedź (rys. 7), a tuż po tym zwraca się w stronę prezentacji (rys. 8), pozwala przykuć większą uwagę widza i podkreślić znaczenie, jakie obecnie przypisuje się w redakcji tego typu produkcjom. Co więcej, nowe rozwiązanie umożliwia nadanie przekazowi odpowiedniego kontekstu, tak że nawet nieinterwencyjny materiał może być w tych okolicznościach przez widza postrzegany właśnie jako taki. Wszystko zmierza do tego, aby odbiorca otrzymał sygnał, że "telewizja oczywiście zajmuje się sprawami każdego, jeśli będzie trzeba, pomoże także Tobie".

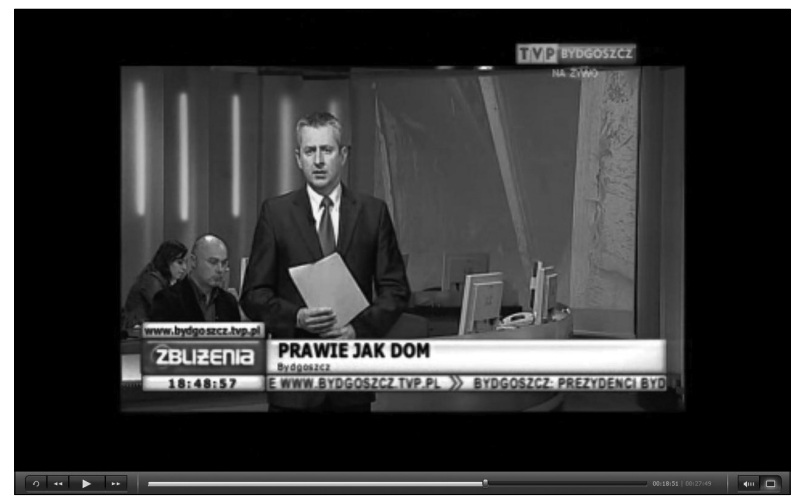

\section{Rysunek 7}

Źródło: www.tvp.pl/bydgoszcz.

teriał, np. matka chorego dziecka, syn zmarłego itp."; $11,9 \%$ to przechodnie, tj. na zasadzie ulicznego sondażu ludzie proszeni o komentarz do danego tematu; należy nadmienić, że w badaniu nie uwzględniono wypowiedzi polityków), można by stwierdzić, że rzeczywiście współtworzą oni przekaz. Trzeba jednak przy tym pamiętać, że wypowiedzi te bywają "starannie" wyselekcjonowane i dobrane tak, żeby pasowały do przyjętej wcześniej przez dziennikarza tezy. Można powiedzieć, że w takim przypadku ludzie nie tworzą przekazu. Są oni raczej „używani” do jego wytworzenia. Szczegóły dotyczące badania IMM - zob. [Wizja świata. Emocje wyzwolone]. 


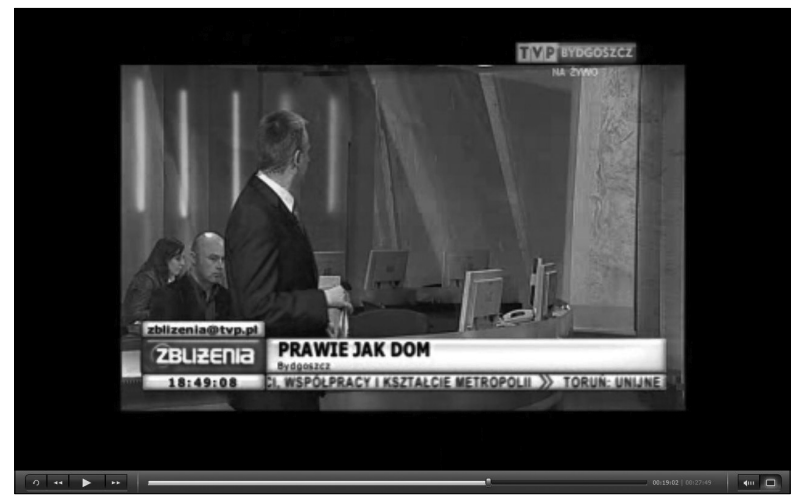

Rysunek 8

Źródło: www.tvp.pl/bydgoszcz.

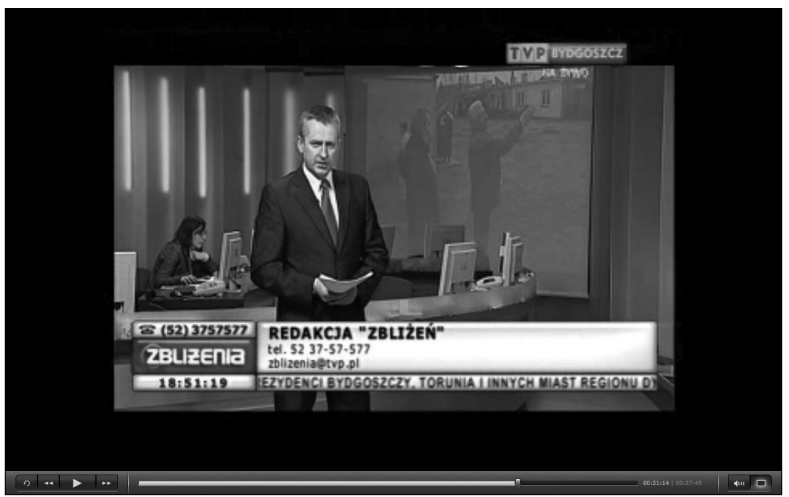

\section{Rysunek 9}

Źródło: www.tvp.pl/bydgoszcz.

Wzmocnienie i potwierdzenie tego przekazu następuje tuż po zakończeniu prezentacji „materiału” i znajduje swoje odzwierciedlenie w słowach prowadzącego, które najczęściej brzmią: „Zajęliśmy się tą sprawą po interwencji (sygnałach) naszych widzów. Dziękujemy za sygnał Panu Krzysztofowi i zachęcamy do kontaktu z naszą redakcją. Nasz nr telefonu to..., adres email..."36. Dzięki temu odbiorcy nie mają też wątpliwości, kto tak naprawdę jest „właścicielem” tej informacji.

Po czwarte: impulsem do kontaktu z redakcją mogą być również „wejścia internetowe”, w których to prowadzący „Zbliżenia”, po krótkim wpro-

${ }^{36}$ Podane przez prezentera dane kontaktowe przez cały czas trwania „Zbliżeń" widnieją na ekranie (rys. 7-9, 11-12). 
wadzeniu informacji, zwraca się o szczegóły do redaktora wydania internetowego (rys. 10 i 11). Dziennikarz informuje o nowościach i bieżącej zawartości WWW. Jest to także okazja do zaprezentowania otrzymanych materiałów, rzadziej od widzów, częściej np. Policji37, i zaproszenia widzów do odwiedzenia witryny. Dzięki temu przekaz nie zostaje zamknięty: telewizja - podobnie portale internetowe - daje widzowi możliwość sięgnięcia po więcej, "otwiera mu okno na świat" ${ }^{\prime 38}$. Wydaje się, że podobną funkcję może pełnić także zapowiedź: rozmowy dnia (rys. 15), prognozy pogody (rys. 16) czy sportu (rys. 13 i 14$)^{39}$.

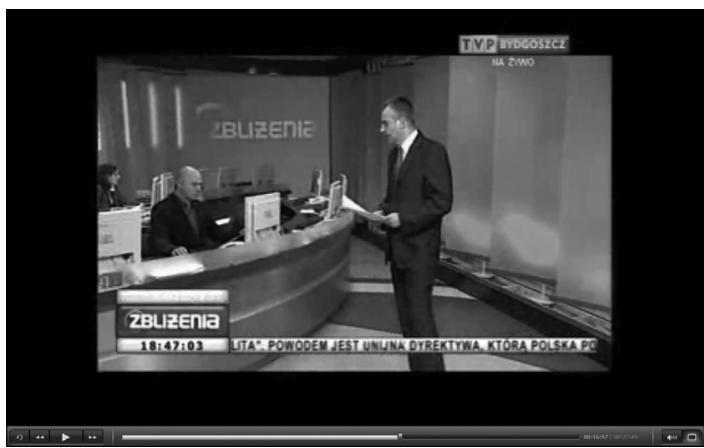

\section{Rysunek 10}

Źródło: www.tvp.pl/bydgoszcz.

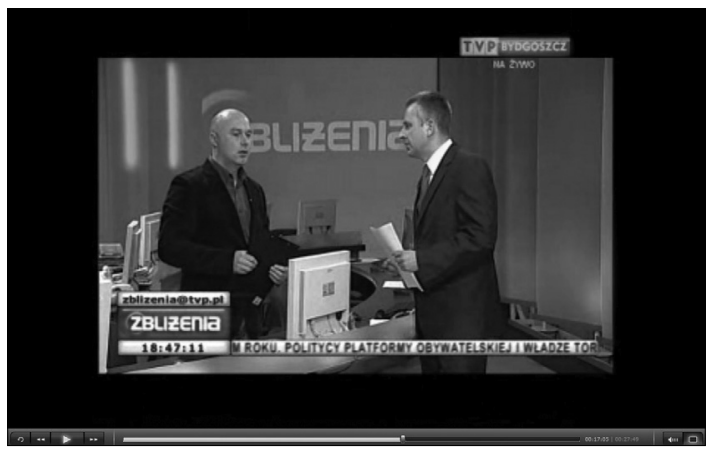

\section{Rysunek 11}

Źródło: www.tvp.pl/bydgoszcz.

${ }^{37}$ Tylko w lutym zdjęcia operacyjne Policji były prezentowane sześć razy.

38 Bowman i Willis [2003: 59] radzą: „Don't leave your product in a cul-de-sac”.

${ }^{39}$ W każdej części programu prezenter rozmawia z osobą prowadzącą poszczególne produkcje o tym, czego „już za chwilę" będzie można się dowiedzieć. Tym samym widz otrzymuje sygnał, że program nie kończy się wraz ze „Zbliżeniami”. Czeka na niego „kolejna dawka informacji". 


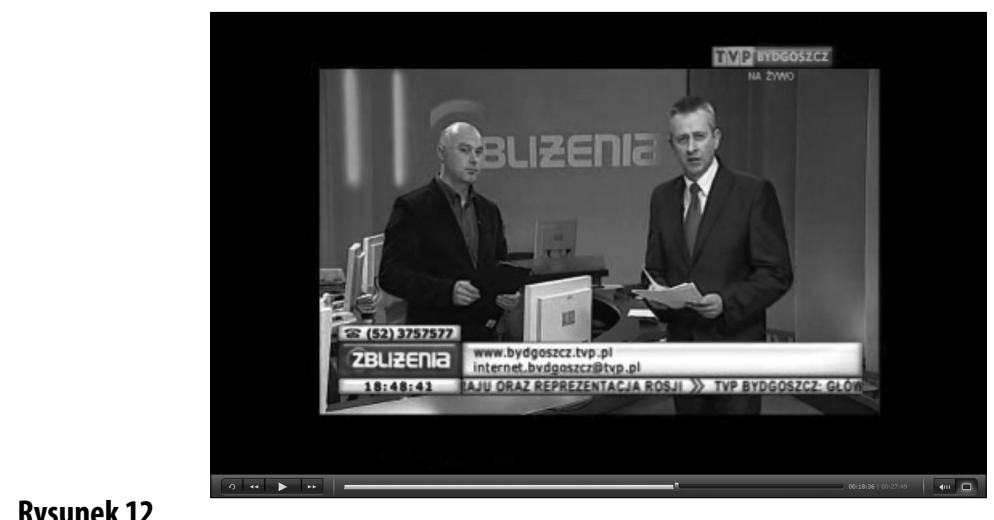

\section{Rysunek 12}

Źródło: www.tvp.pl/bydgoszcz.

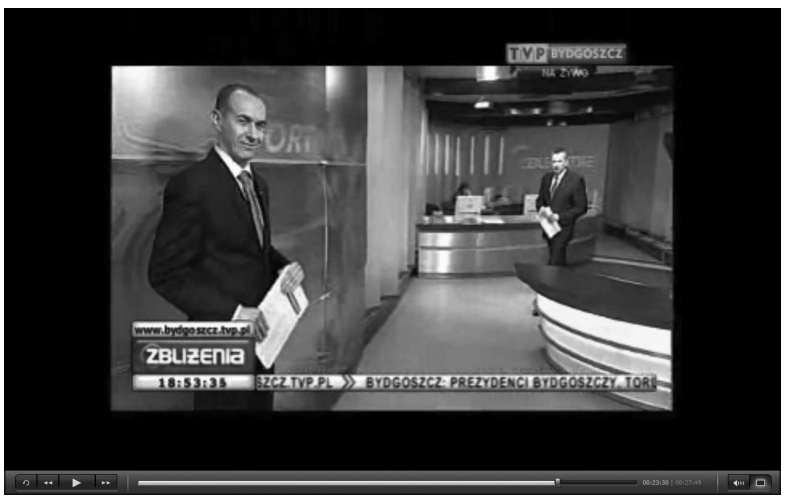

\section{Rysunek 13}

Źródło: www.tvp.pl/bydgoszcz.

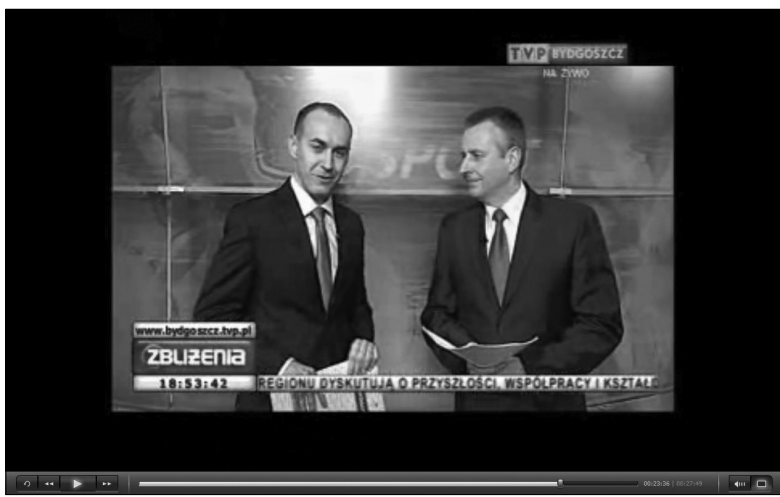

\section{Rysunek 14}

Źródło: www.tvp.pl/bydgoszcz. 
W tej części programu odbiorca po raz kolejny zostaje zaproszony do przesyłania plików i zgłaszania spraw, którymi powinni zająć się reporterzy "Zbliżeń" (rys. 12). „Wejście na żywo" zmierza do wykształcenia u widza i uwiarygodnienia wrażenia ciągłej gotowości i „czujności” redakcji (pokazano przecież „człowieka, który czeka na nas"40). Przekaz wzmacnia dodatkowo lokalizacja opisywanego elementu „Zbliżeń", która - jak wynika z analizy serwisu - najczęściej znajduje się tuż przed lub po „interwencji".

\section{Zagrożenia wynikające z otwarcia się mediów na odbiorcę}

Zaprezentowane przekształcenia, wprowadzone zarówno na płaszczyźnie środków komunikacji, jak i oprawy serwisu, zmierzające do „otwarcia się" telewizji i aktywizacji odbiorcy, należy postrzegać oczywiście w kategoriach szans. Aby ukazać pełny obraz zjawiska, trzeba jednak także wspomnieć o związanych z nim zagrożeniach. Otóż zdaniem autora na uwagę zasługują dwa „procedery". Po pierwsze: niektórzy widzowie, świadomi panującej obecnie w mediach potrzeby bycia „jak najbliżej mowy ulicy i tzw. zwykłych ludzi" [Hajduk-Nijakowska 2010: 11], przekonani o „niezawodności czwartej władzy”, próbują za pośrednictwem mediów załatwiać swoje „partykularne interesy" i „problemy”. Słowem: „gdzie diabeł nie może, tam media pośle". Motywację tych osób można streścić w zdaniu: „Wy będziecie mieli temat, a przy okazji pomożecie mi”. W skrajnych przypadkach ich próby zmierzają do wywierania nacisku na instytucje państwowe, włącznie z wymiarem sprawiedliwości. Zjawisko zostało już zauważone w środowisku dziennikarskim, czego dowodem mogą być apele o rozwagę i ostrożność przy realizacji tego typu materiałów.

Po drugie: motywacje ${ }^{41}$ i zaproszenia medió $\mathrm{w}^{42}$ do „świata reporterskiego" kierowane pod adresem odbiorców powodują, że niezdrowa at-

40 Podobnie o znaczeniu „wejść na żywo" pisze Jacek Skorus [2010: 51-53].

${ }^{41}$ Można wspomnieć choćby o nagrodzie 3 tys. dolarów, która jest przyznawana każdego roku za pierwsze miejsce w konkursie „Relacja z wydarzenia”. Oprócz tego wiele redakcji umożliwia widzom zaistnienie na antenie czy stworzenie własnego profilu, który można uznać za swego rodzaju "CV" reportera. To oczywiście ma podgrzać rywalizację.

42 Poszczególne redakcje prześcigają się w pomysłach, mających zachęcić odbiorców do aktywności. Niektóre oferują poradniki (na stronie www.kontakt24.tvn.pl swoimi radami dzieli się Marek Mazur z Faktów TVN), inne wskazują niezbędne do montażu oprogra- 
mosfera rywalizacji, „pogoni za sensacją" $i$ „,bycia pierwszym”43 udziela się także im. W skrajnych przypadkach prowadzi to do sytuacji, w której „pasjonatów dziennikarstwa" zaczyna bardziej interesować zrobienie "dobrych" zdjęć niż pomoc innym ${ }^{44}$. Wydaje się, że społeczeństwo ogarnęło obecnie "szaleństwo" rejestracji wszystkiego, co dzieje się dookoła - i nie jest to bynajmniej przejściowa moda, „lecz długotrwała tendencja” [Szpunar 2008: 164]. Jak słusznie bowiem stwierdza Henry Jenkins [2007: 128]: „W kulturze łowieckiej dzieci bawią się łukami i strzałami. W społeczeństwie informacyjnym - informacją”. „Zabawa” o tyle pożyteczna, o ile pamiętamy, aby „bawić się z głową”. W sposób szczególny powinni zadbać o to dziennikarze.

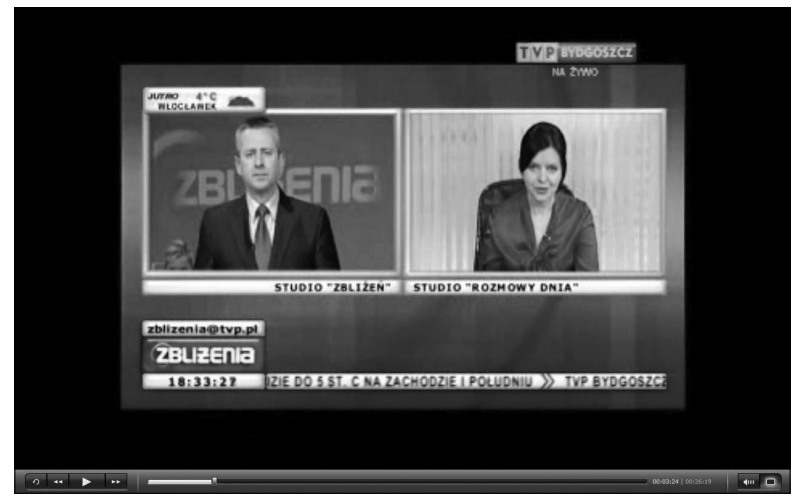

\section{Rysunek 15}

Źródło: www.tvp.pl/bydgoszcz.

mowanie (www.wiadomosci24.pl), a jeszcze inne namawiają do „bycia szybszym niż dziennikarz" (www.Alert24.pl). Każdy sposób, który "wciąga odbiorcę do gry", jest dobry.

${ }^{43}$ Redagujący stronę www.rmf24.pl wręcz odradzają przesyłanie „informacji o wydarzeniach, o których wszyscy już wiedzą. Nikogo to nie zainteresuje”. Liczy się „kto pierwszy ten lepszy" - zob. http://www.rmf24.pl/goraca-linia, 15.04.2011.

${ }_{44}$ Dla przykładu warto tu wspomnieć o przypadku toruńskiego studenta prawa, Artura Gadziomskiego, który w marcu 2011 r., w czasie reanimacji nieprzytomnego mężczyzny, bezskutecznie prosił zgromadzone wokół niego osoby o pomoc. Z jego relacji wynika, że niektórzy „zamiast pomóc, robili zdjęcia komórkami” [Oberlan 2011]. Potwierdzili to ratownicy medyczni, wezwani na miejsce zdarzenia [Goniak 2011]. Podobnych przykładów można wskazać więcej. Problem dostrzegli nawet sami internauci. Jeden z nich tak oto komentuje zachowanie kierowcy, który podczas jazdy samochodem filmuje wypadek drogowy: „Nie wiem, jak nazwać kogoś, kto aby zaistnieć na Kontakt TVN24, naraża bezpieczeństwo swoje i innych" - zob. http://kontakt24.tvn.pl/artykul,smiertelny-wypadek-tiradroga-86-katowice-sosnowiec,47527.html, 26.03.2011. 


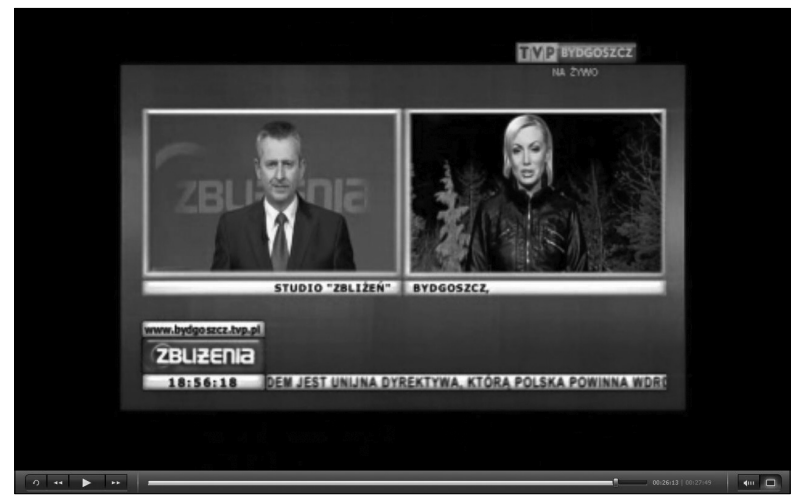

Rysunek 16

Źródło: www.tvp.pl/bydgoszcz.

\section{Podsumowanie - wpływ zmian na pracę dziennikarzy}

Konieczność zachowania większej niż dotychczas czujności i krytycznego podejścia do informacji zaczerpniętych z Internetu to jedno $z$ "wyzwań", przed którym stają obecnie tradycyjni dziennikarze. Bogate wirtualne zasoby to "skarbnica tematów", kryjąca w sobie jednak wiele pułapek. Wbrew pozorom, jak zauważa Skorus [2010: 54-55], szczególnie dla młodych adeptów zawodu, nie jest to takie oczywiste. Internet dla wielu z nich stał się obecnie głównym, a nierzadko jedynym źródłem informacji. Dziennikarz pisze: „wielu młodych reporterów, którzy nie znają życia bez komputera [...], na pytanie starszych kolegów: »gdzie znalazłeś tę informację?« odpowiada bez namysłu - »w Internecie«. »A jak ją zweryfikowałeś?«, "A po co? Przecież była w Internecie!«". Należy zgodzić się z autorem, że obecnie „nastąpił wyraźny kryzys odpowiedzialności” [Skorus 2010: 55].

Czynnik ludzki nie jest jednak jedynym powodem wspomnianej sytuacji. Brak rzetelności nierzadko „wymusza” wzrastające tempo pracy. Triumfy w mediach obecnie święci zasada "kto pierwszy, ten lepszy". Liczy się przecież news - a to, w jakiej formie zostaje podany, jest już mniej ważne. Dlatego media decydują się, po wstępnej weryfikacji, publikować nadesłane przez widzów (bezpośrednich świadków wydarzeń) „pierwsze” informacje. Dopiero z upływem czasu pojawiają się - mniej lub bardziej istotne (konieczne?) - szczegóły.

Wydaje się, że od sytuacji, w której odbiorca staje się „partnerem” żurnalisty, nie ma już odwrotu. Dlatego tak istotne dla przetrwania tradycyj- 
nego dziennikarstwa jest dostosowanie się "do nowego środowiska” nie tylko mediów, ale także samych żurnalistów [Zwiefka-Chwałek 2009: 157]. Obecnie „w środkach masowego przekazu zapanowała niepodzielnie potrzeba nawiązania kontaktu z odbiorcami" [Hajduk-Nijakowska 2010: 10]. Realizuje się ją przez zmianę tematyki i budowy newsa, która do tej pory skutecznie zniechęcała odbiorców do kontaktu. Aktualnie coraz częściej to właśnie oni stają się „bohaterami” wiadomości. Przy wszystkich pozytywnych skutkach tego zjawiska, trzeba jednak pamiętać o zachowaniu pewnego umiaru. Uwzględnienie tego założenia pozwoli uniknąć sytuacji, w której nienadający się do realizacji,temat” (choćby z powodu opisanych w niniejszej pracy zagrożeń) trafi na antenę głównie z powodu braku innych, pozwalających „tworzyć serwis z ludzką twarzą”.

Dodatkowo jeszcze - o czym trzeba wspomnieć w kontekście zmian, jakie z perspektywy pracy dziennikarza „przyniosły nowe media” - wzrasta liczba obowiązków ${ }^{45}$ nakładanych na żurnalistów. Coraz częściej np. są oni "namawiani” przez redakcję do zakładania blogów, które mają zintensyfikować kontakt z odbiorcą. Kolejne, przypisane żurnalistom zadania, przy ograniczonym czasie, powodują, że trzeba z czegoś zrezygnować. Tym "czymś" najczęściej - nawet wbrew woli dziennikarzy - jest po raz kolejny - „jakość informacji".

Autor starał się ukazać najważniejsze przekształcenia, którym aktualnie ulegają tradycyjne media. Zmiany są widoczne i nie pozostają bez wpływu na pracę dziennikarzy. Wzrost tempa pracy i liczby obowiązków oraz modyfikacja tematyki materiałów to najważniejsze z nich. Pojawiają się także zagrożenia, wymagające szczególnej czujności żurnalistów. Zdaniem autora nie są to jednak przeobrażenia na tyle istotne, aby była potrzebna redefinicja zawodu dziennikarza ${ }^{46}$. Wydaje się, że opisane zmiany wpisują się raczej w profesjonalizację zawodu.

${ }^{45}$ Dla przykładu można podać, że obecnie reporter, przygotowujący danego dnia "jedynkę w serwisie”, powinien rano sporządzić krótką notkę. Jako „Temat dnia” trafia ona następnie na portal. Rola pozostałych dziennikarzy kończy się nierzadko na podesłaniu (przekazaniu) internetowemu redaktorowi dyżurującemu kilku ciekawych „zdjęć”, które następnie - po zmontowaniu (w postaci krótkich filmików) - opatrzone komentarzem są umieszczane w sieci.

${ }^{46}$ Autor pomija tu oczywiście fakt braku jednej „dobrej” definicji, która w sposób kategoryczny rozwiałaby wszelkie wątpliwości dotyczące przynależności poszczególnych osób do opisywanego zawodu. 


\section{Bibliografia}

Bauer Zbigniew. 2007. Nowe media. [W:] E. Chudziński (red.). Słownik wiedzy o mediach. Warszawa-Bielsko-Biała: Wydawnictwo Szkolne PWN.

Bowman Shayne, Willis Chris. 2003. We media. How audiences are shaping the future of news and information. The Media Center.

Eco Umberto. 2010. Apokaliptycy i dostosowani. Warszawa: Wydawnictwo W.A.B.

Gillmor Dan. 2003. Foreword. [W:] S. Bowman, Ch. Willis (red.). We media. How audiences are shaping the future of news and information. The Media Center.

Hajduk-Nijakowska Janina. 2010. Odbiorcy w mediach, media dla odbiorców. [W:]

K. Wolny-Zmorzyński (red.). Ludzie polskich mediów: celebryci a redaktorzy. Toruń:Wydawnictwo Adam Marszałek.

Jenkins Henry. 2007. Kultura konwergencji: zderzenie starych i nowych mediów. Warszawa: Wydawnictwa Akademickie i Profesjonalne.

Kiklewicz Aleksander. 2006. Funkcja pragmatyczna wypowiedzi: treść, subkategorie oraz opcje badawcze. „Prawo i Ekonomia”, s. 107-143.

Kononiuk Tadeusz, Michalski Bogdan. 1998. Problemy prawne zawodu dziennikarskiego. Warszawa: Elipsa.

Michalczyk Stanisław. 2006. Dziennikarstwo jako przedmiot refleksji naukowej. [W:] M. Gierula (red.). Współczesny dziennikarz i nadawca. Sosnowiec: Wyższa Szkoła Zarządzania i Marketingu.

Mocek Stanisław. 2006. Dziennikarze po komunizmie: elita mediów w świetle badań społecznych. Warszawa: Scholar, Collegium Civitas Press.

Sartori Giovanni. 2007. Homo videns. Telewizja i postmyślenie. Warszawa: Wydawnictwo Uniwersytetu Warszawskiego.

Skorus Jacek. 2010. Technologiczne uwarunkowania informacji telewizyjnej. [W:] K. Wolny-Zmorzyński (red.). Ludzie polskich mediów: celebryci a redaktorzy. Toruń: Wydawnictwo Adam Marszałek.

Szacka Barbara. 2003. Wprowadzenie do socjologii. Warszawa: Oficyna Naukowa. Szpunar Magdalena. 2008. Dziennikarstwo obywatelskie w dobie Internetu. [W:] K. Grysa (red.). Rola informatyki w naukach ekonomicznych i społecznych. Kielce: Wyższa Szkoła Handlowa.

Zwiefka-Chwałek Agnieszka. 2009. Dziennikarstwo uczestniczqce jako przejaw mediamorfozy. Wrocław: Wydawnictwo Uniwersytetu Wrocławskiego.

Żórawski Kazimierz. 2010. Długi stół. Warszawa: Telewizja Polska. 


\section{Źródła internetowe}

al. 2009. Marcysiak i Lewandowski tworzq nowa telewizję. http://bydgoszcz.gazeta.

pl/bydgoszcz/1,48722,6451874,Marcysiak_i_Lewandowski_tworza_nowa_ telewizje.html, 21.03.2011.

badman. 2010. Śmiertelny wypadek Tira. Droga 86 Katowice-Sosnowiec. http:// kontakt24.tvn.pl/artykul,smiertelny-wypadek-tira-droga-86-katowicesosnowiec,47527.html, 26.03.2011.

Czas po Twojej Stronie. http://brtvp.pl/mozliwosci/TVP.PL/oferta/, 30.03.2011.

Goniak Łukasz. 2011. Gdy ratował życie zawałowcowi, inni tylko patrzyli. http:// www.tvp.pl/bydgoszcz/aktualnosci/spoleczne/gdy-ratowal-zycie-zawalowcowi-inni-tylko-patrzyli/4167503, 29.03.2011.

Goraca linia. http://www.rmf24.pl/goraca-linia, 15.04.2011.

jar. 2011. Bez pieniędzy podatnika misji nie będzie. http://www.express.bydgoski.

$\mathrm{pl} /$ look/article.tpl?ldLanguage $=17 \&$ ldPublication $=2 \&$ Nrlssue $=1773 \& \mathrm{NrSec}-$ tion $=1 \&$ NrArticle $=198814 \&$ IdTag $=18,25.03 .2011$.

jot. 2009. Nowy dyrektor TVB będzie przyglądat się pracownikom i ich pracy. http://www.pomorska.pl/apps/pbcs.dll/article?AID=/20090206/BYDGOSZCZ01/177867030, 20.03.2011.

Napadli parę z dzieckiem. 2011. http://www.tvp.pl/bydgoszcz/aktualnosci/kryminalne/napadli-pare-z-dzieckiem-dla-20-zlotych/4225702, 29.03.2011.

Nietrzpiel Paulina. 2011. "Wiadomości" umacniaja przewagę nad "Faktami”. http:// blogi.satkurier.pl/64374-8222wiadomosci8221-umacniaja-przewage-nad8222faktami8221.html, 9.04.2011.

Oberlan Małgorzata. 2011. Błagałem innych o pomoc. http://www.nowosci.com. $\mathrm{pl} /$ look/nowosci/article.tpl? IdLanguage $=17 \& \mathrm{IdPublication}=6 \& \mathrm{Nrlssu}-$ $\mathrm{e}=1676 \& \mathrm{NrSection}=1 \& \mathrm{NrArticle}=199038,29.03 .2011$.

Poznajcie TVP.pl. http://brtvp.pl/mozliwosci/TVP.PL/, 30.03.2011.

Przybylski Przemysław. 2009. Fotel po Marii Kudroń ani chwilę nie pozostawał pusty. http://www.express.bydgoski.pl/look/nowosci/article.tpl?IdLanguage$=17 \&$ IdPublication $=6 \&$ Nrlssue $=1175 \&$ NrSection $=1 \&$ NrArticle $=128131 \& l d-$ Tag $=38,20.03 .2011$.

RUT. 2010. Programy TVP Bydgoszcz w połowie sponsorowane. http://www.press. $\mathrm{pl} /$ newsy/pokaz.php?id=23763, 25.03.2011.

Szewczyk Łukasz. 2007. Zostań reporterem TVN24. http://media2.pl/media/23782zostan-reporterem-tvn24.html, 30.03.2011.

Uchwała Rady Programowej TVP Bydgoszcz z dnia 2.09.2009 r. http://www.tvp.pl/ bydgoszcz/o-tvp-bydgoszcz/rada-programowa/1849589, 28.03.2011. 
Wizja świata. Emocje wyzwolone. 2010. http://www.instytut.com.pl/raporty/inne, 27.03.2011.

\section{Traditional media vs. new opportunities. Re-definition of the journalism?}

Summary: This paper is a presentation and analysis of changes which have occurred in television news desks under the influence of media convergence. The author especially rises an issue of procedures, some practices and forms of "opening TV broadcasting" (e.g. making it more interactive), focusing not only on the evolution of using the real mass-communication tools (e.g. the Internet), but also putting emphasis on movements which have to "exhibit" (flaunt) phenomenon of interactiveness. The last one, in case of TV, are the special ones. It seems that television has been perceived as a one-way medium (one-to-many; which is the core of TV). Therefore, if it wants to attract the attention of 'the next generation of news consumers' the only thing to do is to "conjure the reality". It turns up in, inter alia, the structure of the news service, text and form of preparing news and publication speed. Those questions are the main object of the analysis described in this article. The important thing is that the mentioned changes have a crucial influence on the journalists and people involved in the message creating procedures. It seems that nowadays this profession is changing "ontologically" and functionally. Is it such a relevant modification that these-days we can talk about redefinition of journalism profession? The answer to this question and description of the modifications are based on a direct observation and analysis of one of the Polish regional service broadcasters. Of course, it seems that similar trends can be successfully observed in many others news organizations and services.

Keywords: democratization of media, interactiveness, media convergence, re-definition of journalism 